\title{
Perlindungan Hukum Bagi Kreditur Pada Perjanjian Jaminan Fidusia
}

\author{
Jatmiko Winarno *) \\ ${ }^{*}$ Dosen Fakultas Hukum Universitas Islam Lamongan
}

\begin{abstract}
ABSTRAK
Dalam perjanjian jaminan fidusia perlindungan hukum bagi kreditur masih dianggap lemah, padahal kreditur juga mempunyai peranan penting dalam kegiatan ekonomi pada umumnya dan penjaminan pada khususnya. Penelitian ini bertujuan untuk mengetahui perlindungan hukum terhadap kreditur agar tercapai kepastian hukum dalam perjanjian jaminan fidusia dengan metode yuridisnormatif.

Untuk memastikan adanya perlindungan hokum bagi kreditur pada perjanjian jaminan fidusia perlu di pahami tentang jaminan fidusia, benda jaminan fidusia dan latar belakang timbulnya perjanjian jaminan fidusia.

Upaya perlindungan hukum kreditur pada perjanjian jaminan fidusia harus memenuhi syarat yang ditentukan dalam pasal 6 dan pasal 11 UUJF. Akan tetapi perlindungan tersebut masih dianggap lemah karena tidak diimbangi dengan ketegasan dalam eksekusi jaminan fidusia.

Pada akhirnya untuk mempertegas perlindungan hukum kreditur dalam perjanjian jaminan fidusia, perlu diimbangi dengan pembentukan lembaga eksekusi jaminan dan sosialisasi tentang pelaksanaan fidusia.
\end{abstract}

\section{Kata Kunci : Perlindungan hukum, kreditur, jaminan fidusia}

\section{A. Pendahuluan}

Jaminan mempunyai fungsi yang sangat penting dalam kegiatan ekonomi pada umumnya karena dalam pemberian pinjaman modal dari lembaga keuangan (baik bank maupun bukan bank) mensyaratkan adanya suatu jaminan, yang harus dipenuhi para pencari modal kalau ia ingin mendapatkan pinjaman/tambahan modal (berupa kredit) tersebut baik untuk jangka panjang maupun jangka pendek.

Bagi pihak debitur bentuk jaminan yang baik adalah bentuk jaminan yang tidak akan melumpuhkan kegiatan usahanya sehari-hari, sedangkan bagi kreditur jaminan yang baik adalah jaminan yang dapat memberikan rasa aman dan kepastian hukum bahwa kredit yang diberikan dapat diperoleh kembali tepat pada waktunya. Salah satu lembaga jaminan yang dikenal dalam sistem hukum jaminan di Indonesia adalah lembaga jaminan fidusia. Fidusia yang berarti penyerahan hak milik atas dasar kepercayaan memberikan kedudukan kepada debitur untuk tetap menguasai barang jaminan, walaupun hanya sebagai peminjam pakai untuk sementara waktu atau tidak lagi sebagai pemilik. Apalagi lembaga fidusia ini dikaitkan pasal 1152 KUH Perdata menyatakan pula. bahwa jika barang jaminan tetap dibiarkan dikuasai debitur maka jaminan tersebut akan tidak sah.

Lembaga Jaminan Fidusia telah.diakui eksistensinva dengan adanya Undang-undang Republik Indonesia Nomor: 42 tahun 1999 tentang Jaminan Fidusia, yang telah diundangkan pada tanggal 30 September 1999.. Sebagaimana diketahui bahwa jaminan Fidusia adalah hak agunan/jaminan atas benda bergerak yang berwujud maupun tidak berwujud, atau yang tidak dapat dibebani hak tanggungan menurut Undang-undang No. 4 tahun 1996 tentang Hak Tanggungan yang dimiliki oleh Penerima Fidusia yang terdaftar di Kantor Pendaftaran Fidusia, yaitu sebagai agunan bagi pelunasan utang tertentu dan yang mempunyai hak untuk didahulukan daripada para kreditor lainnya.

Sedangkan Fidusia adalah pengalihan hak kepemilikan atas suatu benda yang dapat difidusiakan tersebut berdasarkan kepercayaan yang penguasaannya tetap dilakukan oleh si pemilik benda tersebut. Biasanya hal terjadi karena pemilik benda tersebut (debitor) membutuhkan sejumlah uang dan sebagai jaminan atas pelunasan utangnya tersebut si debitor menyerahkan secara kepercayaan hak kepemilikannya atas suatu benda bergerak atau benda yang tidak termasuk dalam lingkup Undang-Undang No. 4 tahun 1996 kepada kreditomya; dan hak tersebut juga dapat dialihkan kepada pihak lain.

Pemberian jaminan fidusia ini merupakan perjanjian yang bersifat accessoir dari suatu perjanjian pokok sebagaimana disebutkan dalam penjelasan Pasal 6-huruf b Undang undang No. 42 
Tahun 1999 dan harus dibuat dengan suatu akta notaris yang disebut sebagai akta Jaminan Fidusia. Pasal 11 jo Pasal 13 jo Pasal 15 Undang-undang Nomor 42 Tahun 1999 menentukan bahwa benda (yang ada di wilayah negara RI atau di luar negara RI) yang dibebani dengan jaminan fidusia wajib didaftarkan di Kantor Pendaftaran Fidusia yang permohonan pendaftarannya diajukan oleh Penerima Fidusia dengan memperhatikan syarat-syarat sebagaimana disebutkan dalam Pasal 13 dan atas dikabulkannya permohonan pendaftaran tersebut, maka kepada penerima fidusia diberikan sertifikat Jaminan Fidusia yang tanggalnya sama dengan tanggal diterimanya permohonan pendaftaran fidusia (registration of titles). Sertifikat Jaminan Fidusia disamakan dengan suatu putusan pengadilan yang telah mempunyai kekuatan hukum tetap (inkracht van gewijsde) yang mempunyai kekuatan eksekutorial (titel eksekusi), artinya Sertifikat jaminan Fidusia tersebut dapat dieksekusi.

Penerima fidusia ini dapat seseorang atau beberapa orang secara bersama-sama (misalnya dalam, pemberian kredit secara konsorsium sebagaimana disebutkan dalam penjelasan Pasal 8), akan tetapi jaminan fidusia ulang tidaklah diperkenankan, artinya pemberi fidusia tidak boleh menjaminkan lagi obyek jaminan fidusia untuk jaminan fidusia utang lain (Pasal 17 UU No. 42 tahun 1999).

Menurut Pasal 11 UUJF dijelaskan bahwa dengan perjanjian fidusia secara akta notarfil tidaklah cukup, tetapi harus didaftarkan, akta notariil merupakan akta otentik dan dapat merupakan utorial akta, dalam perjanjian fidusia akta notariil tanpa pendaftaran tidak memberikan hak preferent bagi penerima fidusia, demikian juga tidak ada pengaturan yang tegas dalam UUJF mengenai siapa yang harus mengeksekusi benda jaminan fidusia, padahal benda jaminan fidusia merupakan benda bergerak yang sangat riskan perpindahannya, akibatnya penerima fidusia dalam penerapan di lapangan sulit melaksanakan asas droit de suite.

Kelemahan-kelemahan perlindungan tersebut di atas diperburuk dengan tindakan praktek penerapan perjanjian fidusia di lapangan, antara lain berupa tidak dilakukannya pendaftaran benda fidusia (hanya berhenti pada pembuatan akta otentik), dilakukannya negosiasi yang memberikan biaya tambahan bagi penerima fidusia pada saat mengeksekusi benda jamainan fidusia, sehingga sertifikat fidusia tidak memberikan pendidikan hukum dalam masyarakat

Tidak mengherankan akibat praktek damai demikian, kasus-kasus lamban dan susahnya eksekusi fidusia menjadi persoalan, dalam prasurvey yang penulis lakukan, misaInya pada beberapa Bank Perkreditan Rakyat perjanjian jaminan fidusia tidak. efektif karena susahnya pelaksanaan eksekusi.

\section{B. Tinjauan Pustaka \\ 1. Pengertian Fidusia}

Fidusia menurut asal katanya berasal dari kata "Fides", yang berarti kepercayaan, Sesuai dengan arti kata ini maka hubutigan (hukum) antara debitor (pemberi kuasa) dan kreditor (penerima kuasa) merupakan hubungan hukum yang berdasarkan kepercayaan.

Pranata jaminan fidusia sudah dikenal dan dibertakukan dalam masyarakat hukum Romawi. Ada dua bentuk jaminan fidusia yaitu fidusia cum creditore dan fidusia cum amico. Keduanya timbul dari perjanjian yang disebut pactum fiduciae yang kemudian diikuti dengan penyerahan hak atau in iure cessio.

Dalam bentuk yang pertama atau lengkapnya fiducia cum creditare contracta yang berarti janji kepercayaan yang dibuat dengan kreditor, dikatakan.bahwa debitor akan mengalihkan kepemilikan atas suatu benda kepada kreditor sebagai jaminan atas utangnya dengan kesepakatan bahwa kreditor akan mengalihkan kembali kepemilikan tersebut kepada debitor apabila utangnya sudah dibayar lunas.

Fidusia merupakan istilah yang sudah lama dikenal dalam bahasa Indonesia. Undang-undang yang khusus mengatur tentang hal ini, yaitu UUJF

juga menggunakan istilah "fidusia". Dengan demikian, istilah "fidusia" sudah

merupakan istilah resmi dalam dunia hukum kita. Akan tetapi, kadang-kadang dalam bahasa Indonesia untuk fidusia ini disebut juga dengan istilah "Penyerahan Hak Milik Secara Kepercayaan". Dalam literatur Belanda jaminan fidusia ini dikenal juga dalam istilah-istilah sebagai berikut :

(1) Zekerheids-eigendom (Hak Milik sebagai Jaminan).

(2) Bezitloos Zekerheidsrecht (jaminan tanpa Menguasai).

(3) Verruimd Pand Begrip (Gadai yang Diperluas).

(4) Eigendom Overdracht tot Zekerheid (Penyerahan Hak Milik - secara jaminan). 
(5) Bezitloos Pand (Gadai tanpa Penguasaan).

(6) Een Verkapt Pand Recht (Gadai Berselubung).

(7) Uitbaouw dari Pand (Gadai yang Diperluas).

Beberapa prinsip utama dan jaminan fidusia adalah sebagai berikut :

(1) Bahwa secara riil, pemegang fidusia hanya berfungsi sebagai pemegang jaminan saja, bukan sebagai pemilik yang sebenamya.

(2) Hak pemegang fidusia untuk mengeksekusi barang jaminan baru ada jika ada wanprestasi dari pihak debitur

(3) Apabila hutang sudah dilunasi, maka objek jaminan fidusia harus dikembalikan kepada pihak pemberi fidusia.

(4) Jika hasil penjualan (eksekusi) barang fidusia melebihi jumlah hutangnya,. maka sisa hasil penjualan harus dikembalikan kepada pemberi fidusia.

Selain itu, agar sahnya peralihan hak dalam konstruksi hukum tentang ini, haruslah memenuhi syarat-syarat sebagai berikut:

(1) Terdapat perjanjian yang bersifat zakelijk.

(2) Adanya fitel untuk suatu peralihan hak.

(3) Adanya kewenangan untuk mengiiasai benda dari orang yang menyerahkan benda.

(4) Cara tertentu untuk penyerahan, yakni dengan cara constitutum posessorium bagi benda bergerak yang berwujud, atau dengan cara cessie untuk hufang piutang.

Bila dicermati konstruksi hukum di atas merupakan ciri dari perjanjian fidusia, yaitu bahwa memang hakekat dari perjanjian fidusia merupakan perjanjian terhadap suatu benda (kebendaan), titel peralihan hak sebagai syarat jelasnya perjanjian sekaligus menterjemahkan adanya hukum jaminan. Dalam perjanjian fidusia tersebut, kewenangan menguasai benda, yang dimaksud adalah pelimpahan kewenangan untuk menguasai benda jaminan, tetapi hal ini perlu digaris bawahi kewenangan menguasai tidaklah boleh sama dengan kehendak menguasai, karena kehendak menguasai merupakan bagian yang dilarang dalam perjanjian fidusia, pelimpahan kewenangan lebih merupakan bagian dari tanggung jawab yang diberikan pemberi fidusia kepada penerima fidusia untuk menyelesaikan pinjamannya dengan cara menjual benda jaminan, penyerahan yang dimaksud lebih bersifat simbolis seperti penyerahan secara constituttun posessoriuni bagi benda bergerak yang berwujud, atau dengan cara cessie untuk hutang piutang.

Terhadap penyerahan secara constitutum posessorium, pertu diketahui bahwa dikenal juga beberapa bentuk penyerahan secara tidak nyata, yaitu:

- traditio brevi manu, yaitu suatu bentuk penyerahan di mana barang yang akan diserahkan karena sesuatu hal sudah berada dalam penguasaan pihak yang akan menerima penyerahan, misalnya penyerahan dalam sewa-beli. Pihak penyewa-beli karena perjanjian sewa-beli itu sudah menguasai barangnya sedangkan pemilikannya tetap pada pihak penjual, apabila harga sewa-beli, itu sudah dibayar lunas maka barulah pihak penjual menyerahkan (secara traditio brevi manu) barangnya kepada penyewa-beli dan kemudian menjadi miliknya.

- traditio longa manu, yaitu suatu bentuk penyerahan di mana barang yang akan diserahkan berada dalam penguasaan pihak ketiga.

Misalnya, A membeli sebuah mobil dari B dengan syarat bahwa mobilnya diserahkan seminggu setelah perjanjian jual-beli itu dibuat. Sebelum jangka waktu satu minggu itu lewat A menjual lagi mobil itu kepada $\mathrm{C}$ sedang B diberitahu deh A agar mobil itu nanti diserahkan kepada C saja. Bentuk jual-beli yang demikian sudah biasa dilakukan. bagi dunia usaha, maka dibentuklah perjanjian jaminan fidusi

Meskipun secara praktek fidusia bukan barang baru di Indonesia, tetapi ketentuan perundangundangannya baru ada pada tahun 1999 dengan UUJF pada tanggal 30 September 1999 dan pada hari itu juga diundangkan dalam Lembaran negara nomor 168. UUJF tidak muncul begitu saja, tetapi merupakan reaksi atas kebutuhan dan pelaksanaan praktek fidusia yang selama ini berjalan, maka kiranya akan lebih mudah bagi kita untuk mengerti ketentuan--ketentuan UUJF, kalau kita memahami praktek dan permasalahan praktek yang selama ini ada. Reaksi yang dimaksud salah satunya adalah lesunya perekonomian saat itu, dimana kebutuhan akan modal yang tinggi tidak diimbangi oleh penyediaan modal yang cukup, sehingga dalam rangka efisiensi modal maka pinjaman dilakukan hanya sebatas pada pembelian alat-alat produksi yang belum ada, sedangkan terhadap alat-alat 
produksi yang sudah ada tidak lagi perlu untuk diperbaharui tetapi tetap digunakan sekaligus dijadikan bagian dari jaminan atas pinjaman utang untuk usaha, konsep tersebut merupakan reaksi atas inefisiensi dari perjanjian jaminan gadai yang selama ini dikenal dalam praktek, dimana benda jaminan harus berada dalam penguasaan perierima gadai, kondisi demikian menghambat bagi dunia usaha, maka dibentulah perjanjian jaminan fidusia.

Pasal 1 Undang-undang fidusia memberikan batasan dan pengertian berikut:

"Fidusia adalah pengalihan hak kepemilikan suatu benda atas dasar kepercayaan dengan ketentuan bahwa benda yang hak kepemilikannya dialihkan tetap dalam penguasaan pemilik benda. jaminan fidusia adalah hak jaminan atas benda bergerak baik yang berwujud maupun yang tidak berwujud dan benda tidak bergerak khususnya bangunan yang tidak dapat dibebani hak tanggungan sebagaimana dimaksud dalam Undang-undang Nomor 4 Tahun 1996 tentang Hak Tanggungan yang tetap berada dalampenguasaan Pemberi Fidusia, sebagai agunan pelunasan utang tertentu, yang memberikan kedudukan yang diutamakan kepada penerima Fidusia terhadap kreditor lainnya".

Piutang adalah hak untuk menerima pembayaran. Benda adalah segala sesuatu yang dapat dimiliki dan dialihkan, baik yang berwujud maupun yang tidak berwujud, yang terdaftar maupun yang tidak terdaftar, yang bergerak maupun yang tidak bergerak yang tidak dapat dibebani hak tanggungan atau hipotik. Pemberi fidusia adalah orang perseorangan atau korporasi pemilik benda yang menjadi obyek jaminan fidusia.

Utang adalah kewajiban yang dinyatakan atau dapat dinyatakan dalam jumlah uang baik dalam mata uang Indonesia atau mata uang lainnya, baik secara langsung maupun kontijen. Kreditor adalah pihak yang mempunyai piutang karena pelanjian atau undang-undang. Setiap Orang adalah perseorangan atau korporasi".

Dari definisi yang diberikan tersebut jelas bagi kita bahwa fidusia dibedakan dari jaminan fidusia, dimana fidusia adalah suatu proses pengalihan hak kepemilikan dan jaminan fidusia adalah jaminan yang diberikan dalam bentuk fidusia. Ini berarti pranata jaminan fidusia yang diatur dalam UUJF ini adalah pranata jaminan fidusia sebagaimana yang dalam fiducia cum creditore contracta9, yaitu jaminan yang dibebankan atas suatu benda bergerak secara fidusia sebagai bagian yang disebut pemberian jaminan dengan kepercayaan, jaminan fidusia lebih dikedepankan dalam UUJF dari pada pengertian fidusia itu sendiri, hal ini didasarkan bahwa sebenarnya maksud dari perjanjian fidusia yang dibuat berdasarkan UUJF pada dasarnya adalah proses hubungan hokum dalam dunia usaha yang bertumpu pada unsur saling membantu dan itikad baik pada masing-masing pihak, hal ini dapat terlihat dengan konsepsi fidusia dan jaminan dalam perjanpan ridusia itu sendiri yang sejak awal sampai dengan perkembangannya sekarang berciri khas tidak adanya penguasaan benda jaminan oleh penerima fidusia, padahal terhadap benda bergerak keadaan tersebut sangat beresiko.

Dalam perkembangan fidusia telah terjadi pergeseran mengenai kedudukan para pihak. Pada zaman Romawi kreditor penerima fidusia berkedudukan sebagai pemilik atas barang yang difidusiakan, tetapi sekarang penerima fidusia hanya berkedudukan sebagai pemegang jaminan saja. Ini berarti pada zaman Romawi penyerahan hak milik pada fidusia cum creditore terjadi secara sempuma sehingga kedudukan penerima fidusia sebagai pemilik yang sempurna juga. Konsekuensinya, sebagai pemilik ia bebas berbuat sekehendak hatinya atas barang tersebut. Namun berdasarkan fides penerima fidusia berkewajiban mengembalikan hak milik itu jika beri fidusia melunasi utangnya.

Mengenai hal ini, Dr.A Veenhoven menyatakan bahwa:

Hak milik itu sifatnya sempuma yang terbatas tergantung syarat tertentu. Untuk fidusia, hak miliknya tergantung pada syarat putus (ontbindende voorwaarde). Hak milik yang sempuma baru lahir jika pemberi fidusia tidak memenuhi kewajibannya.

Pendapat tersebut sebenamya belum. jelas terutama yang menyangkut kejelasan kedudukan penerima fidusia selama syarat putus tersebut belum terjadi.

Pembebanan kebendaan dengan jaminan fidusia dibuat dengan Akta Notaris dalam. Bahasa Indonesia yang merupakan akta Jaminan Fidusia (Pasal 5 ayat (1) UU jaminan Fidusia). Dalam Akta Jaminan Fidusia tersebut selain dicantumkan mengenai hari dan tanggal, juga dicantumkan mengenai waktu (jam) pembuatan akta tersebut. 
UUJF menetapkan perjanjian fidusia harus dibuat dengan akta notaris. Apalagi mengingat obyek jaminan fidusia pada umumnya adalah barang bergerak yang tidak terdaftar, maka sudah sewajarnya hukum berkenaan dengan obyek jaminan fidusia. Disamping itu akta otentik merupakan alat bukti yang karena dibuat oleh pejabat Negara (Notaris).

Sebelum undang-undang ini dibentuk lembaga ini disebut dengan macam-macam nama. Zaman Romawi menyebutnya "fiducia cum creditore," Asser Van Oven menyebutnya "zekerheidscigendom" (hak milik sebagai jaminan), Blom menyebutnya "bezitloos zekerheidsrerecht" (hak jaminan tanpa penguasaan), Kahrel member nama "Verruimd Pandbegrip" (pengertian gadai yang diperluas), A. Veenhoven menyebutnya "eigendoms overdracht tot zekerheid" (penyerahan hak milik sebagai jaminan) sebagai singkatan dapat dipergunakan istflah "fidusia" saja. Menurut penulis pengertian fidusia adalah hak milik sebagai jaminan juga benar karena memang yang dapat dibebankan dengan jaminan fidusia harus benar merupakan milik pemberi fidusia dan bukan milik orang lain atau pihak lain (pihak ketiga), pengertian hak jaminan tanpa penguasaan juga memiliki dasar pemikiran karena dalam fidusia memang benda dibebankan sebagai jaminan tanpa adanya penguasaan atas benda jaminan tersebut oleh penerima fidusia, sedangkan terhadap pandangan gadai yang diperluas jika berpatokan pada pelaksanaan gadai yang lebih dikenal saat itu maka wajar praktek fidusia dianggap sebagai begian dari praktek gadai dalam tata cara yang lain, namun menurut penulis hal demikian belumlah tepat, sedangkan dalam pandangan A. Veenhoven disebutkan sebagai penyerahan hak milik sebagai jaminan didasarkan pada kenyataan bahwa memang dalam perjanjian fidusia hak milik dibebankan sebagai jaminan, walau banyaknya pendapat-pendapat mengenai fidusia, namun pendapat-pendapat tersebut tidak jauh dari pengertian fidusia yang kita

kenal dalam praktek.

Fidusia dalam bahasa Indonesia disebut juga dengan istilah "penyerahan hak milik secara kepercayaan". Dalam terminology Belandany sering disebut dengan istilah tengkapnya berupa Fiduciare Eigendonts Overdracht (FEO), sedangkan dalam bahasa Inggrisnya secara fengkap sering disebut dengan istilah Fiduciary Transfer of Ownership

Digunakannya pengertian penyerahan hak milik secara kepercayaan lebih didasarkan pada konsepsi praktek yang coba rangkum dalam UUJF sebagai hal-hal dasar yang akan ingin di atur dalam UUJF, dari rumusan hak milik dasar yang dimaksud adalah benda jaminan harus merupakan hak milik dari pemberi fidusia, sedangkan penyerahan secara kepercayaan adalah penekanan praktek untuk memberikan landas hukum yang selama ini dikenal dalam fidusia. Yaitu pembebanan jaminan atas benda tanpa adanya penguasaan penerima fidusia terhadap fisik benda tersebut.

Adapun unsur-unsur perumusan fidusia sebagai berikut:

a. Unsur secara kepercayaan dari sudut pemberi fidusia;

Unsur kepercayaan memang memegang peranan penting dalam fidusia dan hal ini juga tampak dari penyebutan unsur tersebut di dalam UUJF arti kepercayaan selama ini diberikan oleh praktek, yaitu

- Debitor pemberi jaminan percaya, bahwa benda fidusia yang diserahkan olehnya tidak akan benar-benar dimiliki oleh kreditor penerima jaminan tetapi hanya sebagai jaminan saja ;

- Debitor pemberi jaminan percava bahwa kreditor terhadap benda jaminan hanya akan menggunakan kewenangan yang diperolehnya sekedar untuk melindungi kepentingan sebagai kreditor saja;

- Debitor pemberi jaminan percaya bahwa hak milik atas benda jaminan akan kembali kepada debitor pemberi jaminan kalau hutang debitor untuk mana diberikan jaminan fidusia dilunasi.

b. Unsur kepercayaan dari sudut penerima fidusia, disini penerima fidusia percaya bahwa barang yang menjadi jaminan akan dipelihara/dirawat oleh pemberi fidusia;

c. Unsur tetap dalam penguasaan pemilik benda

d. Kesan ke luar tetap beradanya benda jaminan di tangan pemberi fidusia;

e. Hak Mendahului (preferen)

f. Sifat accessoir.

Adapun yang menjadi dasar hukum fidusia sebelum UUJF dibentuk yurisprudensi arrest HGH tanggal 18 Agustus 1932 tentang perkara melawan Clygnett. Kasus tersebut dijadikan dasar hukum pada praktek fidusia disebabkan adanya terobosan yang mendasarkan putusan HGH bahwa perjanjian yang muncul dan mengatur hubungan hokum pihak kedua adalah Fidusia.

Pengertian jaminan fidusia itu sendiri adalah hak jaminan atas benda baik yang berwujud maupun yang tidak bewujud dan benda tidak bergerak khususnya bangunan yang tidak dapat dibebani 
hak tanggungan bagaimana yang dimaksud dalam Undang-Undang Nomor 4 Tahun 1996 tentang Hak Tanggungan yang tetap berada dalam penguasaan Pemberi Fidusia, sebagai agunan bagi pelunasan utang tertentu, yang memberikan kedudukan yang diutamakan kepada Penerima Fidusia terhadap kreditor lainnya. Dengan adanya UUJF maka penerima fidusia diberikan hak sebagai kreditur preferen atas piutangnya, kedudukan tersebut sama dengan kedudukan yang diberikan terhadap pemegang kreditur Hak Tanggungan berdasarkan tingkatan-tingkatannya.

\section{Benda jaminan Fidusia}

UUJF adalah :

Benda-benda sebagai obyek jaminan fidusia berdasarkan Pasal 1

"Benda adalah segala sesuatu yang dapat dimiliki dan dialihkan baik yang berwujud maupun tidak berwujud, yang terdaftar maupun tidak terdaftar, yang bergerak maupun yang tidak bergerak yang tidak dapat dibebani hak tanggungan atau hipotik".

Lebih lanjut pengaturan mengenai benda jaminan fidusia diatur lagi dalam Pasal 3 UUJF:

Undang-undang ini tidak berlaku terhadap:

a. Hak Tanggungan yang berkaitan dengan tanah dan bangunan, sepanjang peraturan perundangundangan yang berlaku menentukan jaminan atas benda-benda tersebut wajib didaftar;

b. Hipotik atas kapal yang terdaftar dengan isi kotor berukuran 20M3 atau lebih;

c. Hipotik atas pesawat terbang; dan

d. Gadai.

Dapat disimpulkan bahwa benda jaminan fidusia adalah benda bergerak atau yang dipersamakan, sehingga maksud dalam huruf $\mathrm{b}$ di atas bahwa dasar ukuran 20M3 merupakan batas ukuran yang digunakan bagi yang tidak dapat difidusiakan, sedangkan terhadap huruf c lebih lanjut dijelaskan dalam up grading dan refresing course pada Konferda I.N.I. Jawa Tengah pada tanggal.1213 April 2003 bahwa Pesawat Terbang dapat difidusiakan tetapi terhadap mesinnya (engine) dapat diletakkan fidusia.

Dalam ketentuan menyangkut benda jaminan fidusia juga ditegaskan, bangunan di atas tanah orang lain yang tidak dibebani dengan Hak Tanggungan berdasarkan Undang-Undang Nomor 4 Tahun 1996 tentang Hak Tanggungan dapat dijadikan obyek jaminan fidusia.

Terhadap benda jaminan fidusia hal penting yang perlu dicermati adalah menyangkut prinsip benda fidusia haruslah merupakan benda milik pemberi fidusia dan bukan merupakan benda yang berada dalam status kepemilikan orang lain.

Mengenai penjelasan dari benda-benda yang disebutkan dalam pasal tersebut di atas beberapa penulis menyebutkin sebagai berikut:

- Kebendaan yang bertubuh dan tak bertubuh (KUHPerdata Pasal 503),

- Kebendaan adalah bertubuh apabila berwujud. Tak bertubuh (tak berwujud) adalah hak-hak seperti hak atas merek, hak mengarang, piutang dan segala hak-hak untuk menuntut sesuatu.

- Benda bergerak dan tak bergerak

Pembuat undang-undang mengadakan 2 (dua) golongan kebendaaan bergerak, yaitu17: benda bergerak karena sifatnya dan kebendaan bergerak karena ketentuan undang-undang.

(1) Benda bergerak karena sifatnya (Pasal 509 KUHPerdata dan Pasal 510 KUHPerdata) Benda yang dapat berpindah atau dipindahkan adalah benda bergerak menurut sifatnya (Pasal 50 KUHPerdata). Dalam Pasal 510 KUHPerdata diberikan beberapa contoh, antara lain kapal dan sebagainya. Rumusan dari pasal 509 adalah terlalu luas. Tidak semua benda yang dapat berpindah atau dipindahkan adalah benda bergerak. Misalnya alat-alat pabrik, bahan pembangunan yang berasal dari perombakan gedung yang dipergunakan untuk mendirikan gedung itu kembali dan banyak benda-benda yang disebutkan dalam Pasal 507 KUHPerdata dapat berpindah atau dipindahkan, tetapi benda-benda itu menurut Pasal 507 KUHPerdata adalah tak bergerak karena peruntukannya dan dengan demikian bukan merupakan benda bergerak. Kapal adalah benda bergerak, karena dapat dipindahkan, tetapi mengenai penyerahan dan pendaftaran, kapal yang bobot matinya melebihi 20 M3 diperlakukan sebagai benda tak bergerak.

(2) Kebendaan bergerak karena ketentuan undang-undang (Pasal 511 KUHPerdata)

Kebendaan bergerak dari golongan ini adalah kebendaan yang bertubuh, yaitu hak-hak dan tuntutan-tuntutan. Seperti juga mengenai kebendaan bergerak karena sifatnya, kita dapat mengatakan, bahwa kebendaan bergerak karena ketentuan undang-undang adalah hak-hak dan 
tuntutaii-tuntutan yang tak dianggap sebagai kebendaan tak bergerak karena ketentuan undangundang. Pada umumnya obyek dari hak-hak itau tuntutan-tuntutan itu adalah benda-benda bergerak (yang bertubuh). Yang harus diperhatikan bahwa saham-saham dari perseroan dagang dianggap sebagai kebendaan bergerak (yang tak bertubuh), juga apabila perseroan-perseroan itu memiliki kebendaan tak bergerak (Pasal 511 sub 4 KUHPerdata).

Mengenai benda yang menjadi obyek jaminan fidusia ini harus disebutkan secara riil dalam akta jaminan fidusia (Pasal 6 UUJF). Penyebutan tidak hanya tertuju kepada banyaknya/ satuannya dan jenisnya saja, tetapi biasanya dirinci lebih lanjut seperti mereknya, ukurannya, kualitasnya, keadaannya (baru atau bekas), wamanya, nomor serinya, dan kendaaraan bermotor juga disebutkan nomor rangka, nomor mesin, nomor Polisi dan B.P.KB-nya. Khusus mengenai kendaraan bermotor ini pemilik benda adalah bukan nama yang tercantum dalam B.P.K.B maka pemberi fidusia harus melampirkan kuitansi/faktur pembelian atas kendaraan bermotor tersebut.

Kesemuanya itu untuk menghindarkan sengketa yang kemungkinan dapat terjadi di kemudian hari. Pada bank-bank tertentu, kalau pemberian jaminan fidusia itu dilakukan dengan akta di bawah tangan, telah tersedia blangko formulir yang diisi dengan penyebutan socara rinci benda obyek fidusia.

Karena pentingnya pengertian mengenai Benda yang dapat menjadi obyek jaminan fidusia maka menurut hemat penulis dalam UUJF hanya mengenai benda yang menjadi jaminan fidusia harus dijelaskan dengan pasal tersendiri.

\section{Latar Belakang Perjanjian jaminan Fidusia}

Lembaga jaminan fidusia di Indonesia bukan merupakan lembaga baru. Sudah sejak lama kita mengenal lembaga jaminan tersebut, bahkan dalam Penjelasan UUJF diakui bahwa lembaga jaminan fidusia sudah digunakan sejak jaman penjajahan Belanda. Bedanya hanyalah, bahwa lembaga fidusia sebelum berlakunya UUJF, didasarkan pada yurisprudensi dan belum diatur dalam perundangundangan secara lengkap dan komprehensif, sehingga belum menjamin kepastian hukum, sedangkan. yang sudah ada sekarang didasarkan pada UUJF dan diatur secara lengkap dan menjamin kepastian hukum bagi para pihak.

Pasal 584 KUHPerdata mensyaratkan adanya hubungan hukum yang bermaksud untuk memindahkan hak milik, seperti misalnya yang selama ini diakui jual beli, tukar menukar, hibah dan.sebagainya. Dengan pendirian pengadilan seperti tersebut di atas, berarti bahwa Penyerahan Hak Milik sebagai jaminan sekarang diakui sebagai title yang sama sahnya seperti jual beli dan lain-lain.

Lembaga Fidusia di Indonesia untuk pertama kalinya mendapatkan pengakuan dalan keputusan HGH. Tanggal 18 Agustus 1932 - dalam perkara antara B.P.M melawan Dignett - yang mengatakan bahwa title XX Buku 11 Kitab Undang-Undang Hukum Perdata. Memang mengatur tentang gadai, akan tetapi tidak menghalang-halangi para pihak untuk mengadakan perjanjian yang lain dari pada perjanjian gadai, bilamana perjanjian gadai tidak cocok untuk mengatur hubungan hukum antara mereka. Perjanjian Fidusia dianggap

bersifat memberikan jaminan dan tidak dimaksudkan sebagai perjanjian gadai. Duduk perkaranya secara singkat adalah sebagai berikut:

Pedio Clygnett - selanjutnya disebut : Clygnett - meminjam uang dari Bataafse Petrolium Maatschappy - selanjutnya disebut B.P.M. - dan sebagai jaminan ia telah menyerahkan hak miliknya atas sebuah mobil; mobil tersebut tetap ada dalam penguasaan Clygnett,tetapi selanjutnya bukan sebagai pemilik tetapi sebagai peminjam pakai. Jadi ada penyerahan. Secara constitutum possessorium. Dalam perjanjian disepakati, bahwa pinjam pakai itu akan diakhiri antara lain, kalau Clygnett wanprestasi dan dalam hat demikian Clygnett wajib untuk menyerahkan mobil tersebut kepada B.P.M. Ketika Clygnett benar-benar wanprestasi, maka p1 hak B.P.M mengakhiri perjanjian pinjam pakai tersebut di atas dan menuntut penyerahan mobil jaminan, yang ditolak oleh pihak Clygnett dengan mengemukakan sebagai alasan, bahwa mobil tersebut bukan milik B.P.M dan. perjanjian yang ditutup antara mereka adalah perjanjian gadai. Karena mobil yang dijadikan jaminan tetap dibiarkan dalam penguasaan dirinya maka perjanjian gadai tersebut batal.

Ketika perkara tersebut sampai pada Hooggerechtshof Batavia, maka HGH menolak alasan Clygnett dart mengatakan, bahwa Perjanjian Penjaminan itu adalah suatu penyerahan hak milik secara kepercayaan atau fidusia yang sah. Pernyataan dari HGH adalah sebagai berikut: 
- tidak benar bahwa barang bergerak hanya dapat dipergunakan untuk menjamin pembayaran sesuatu utang dengan mengadakan hak gadai atas barang tersebut;

- diaturnya hak gadai dalam Bab XX Buku I KUHPerdata tidak berarti bab tersebut mengahalanghalangi pembuatan perjanjian lain dari. pada gadai, apabila gadai temyata tidak cocok untuk hubungan antara kreditor dan debitor;

- pada perjanjian lain itu, untuk menjamin pembayaran utangnya, debitor boleh menyerahkan hak eigendomnya atas sesuatu barang bergerak kepada kreditornya dengan ketentuan, bahwa barang bergerak tersebut tetap berada di tangan debitor;

- tidak benar bahwa para pihak bermaksud untuk mengadakan hak gadai; para pihak justru tidak menghendaki perjanjian gadai, karena dengan perjanjian gadai pemberi gadai harus menyerahkan barang gadai;

- ketentuan undang-undang tentang hak gadai tidak memaksa kita untuk menyimpulkan, bahwa pengundang-undang menghendaki bahwa barang-barang bergerak yang berada di tangan debitor tidak dapat digunakan untuk menjamin sesuatu utang.

Dengan diundangkannya Undang-Undang RI Nomor 42 tahun 1999 tentang Jaminan Fidusia yang untuk selanjutnya disebut UUJF maka pembuat undang-undang kita sudah memilih untuk mengatur fidusia dalam bentuk tertulis. Dikeluarkannya UUJF merupakan pengakuan resmi dari undangundang akan lembaga jaminan fidusia, yang selama ini peroleh pengakuannya melalui yurisprudensi.

\section{Ruang Lingkup dan Obyek Perjanjian Jaminan Fidusia}

UU Jaminan Fidusia secara jelas menegaskan bahwa jaminan fidusia adalah agunan atas kebendaan atau jaminan kebendaan (zakelijke zekerheid atau security right in rem) yang memberikan kedudukan yang didahulukan kepada penerima fidusia, dimana hak yang didahulukan dari penerima fidusa ini menurut ketentuan Pasal 1 butir 2 UU Jaminan Fidusia tidak hapus dengan pailitnya pemberi jaminan fidusia tersebut. Lebih lanjut dalam ketentuan Pasal 4 UU Jaminan Fidusia ditegaskan bahwa jaminan fidusia merupakan perjanjian ikutan atau eksesor (accesoir) dari suatu perjanjian pokok. Oleh karena itu maka sebagai akibat dari sifat aksesor ini adalah bahwa jaminan fidusia hapus demi hukum bilamana utang yang dijamin dengan jaminan fidusia hapus.

Adapun utang yang pemenuhannya dapat dijamin dengan jaminan fidusia menurut Fred B.G Tumbuan tidak terbatas pada pengertian utang sebagaimana dimaksud dalam ketentuan Pasal I butir 2 jo. Pasal 7 UU Jaminan Fidusia. Menurut Fred B.G Tumbuan utang ini juga mencakup setiap perikatan (verbintenis) sebagaimana dimaksud dalam ketentuan Pasal Pasal 1234 KUHPerdata.

Menurut UU No. 42 Tahun 1999 pengaturan jaminan Fidusia juga mengenai obyek yang dapat dibebani dengan jaminan Fidusia, dalam arti bahwa di luar jaminan-jaminan yang ditentukan dalam UU Jaminan Fidusia tersebut dapat dibebankan dengan fidusia. Berdasarkan ketentuan Pasal 1 UU No. 42 Tahun 1999 dapat diketahui bahwa obyek jaminan fidusia adalah :

1. Benda Bergerak:

a. Berwujud

b. Tidak berwujud

2. Benda tidak bergerak yang tidak dapat dibebani Hak Tanggungan.

Ketentuan Pasal 3 mengatur lebih lanjut mengenai ketentuan Pasal 1 ayat (2) UU No. 42 tabun 1999 menyebutkan bahwa undang-undang ini tidak berlaku terhadap :

1. Hak tanggungan yang berkaitan dengan tanah dan bangunan, sepanjang peraturan perundangundangan yang berlaku menentukan jaminan atas benda-benda tersebut wajib didaftar;

2. Hipotek atas kapal yang terdaftar dengan isi kotor berukuran 20 (dua puluh) M3 atau lebih;

3. Hipotek atas pesawat terbang; dan

4. Gadai

Lebih lanjut UU Fidusia mengatur bahwa selain benda yang sudah dimiliki pada saat dibuatnya jaminan fidusia, maka benda yang diperoleh di kemudian hari dapat juga dibebani dengan jaminan fidusia sebagaimana tampak pada ketentuan Pasal 9 ayat (1) UU Jaminan Fidusia. Hal ini berarti bahwa benda tersebut demi hukum akan dibebani jaminan fidusia nada saat benda tersebut menjadi milik pemberi fidusia.

Mengenai bentuk pejanjian fidusia maka ketentuan Pasal 5 ayat (1) UU Jminan Fidusia menegaskan bahwa untuk perjanjian fidusia harus tertulis dan harus dibuat dengan akta notaris dalam bahasa Indonesia. 
Latar belakang UU menentukan bahwa perjanjian fidusia harus dibuat dengan akta notaris adalah dalam ketentuan Pasal 1870 KUHPerdata yang menyatakan bahwa akta notaris merupakan akta otetitik yang memiliki kekuatan pembuktian sempuma tentang apa yang dimuat didalamnya antara para pihak beserta para ahli warisnya atau para penggantinya. Kenyataan dalam praktek mendukung ketentuan ini mengingat bahwa pada umumnya obyek jaminan fidusia adalah barang bergerak yang tidak terdaftar sehingga akta otentiklah yang paling dapat memberikan jaminan kepastian hukum berkaitan dengan obyek jaminan fidusia tersebut.

Jaminan fidusia lahir pada tanggal jaminan fidusia dicatat dalam pemegang jaminan fidusia adalah Sertifikat jaminan Fidusia vang diterbitkan pada tangga yang sama dengan tanggal penerimaan permohonan pendaftaran jaminan fidusia sebagaimana diatur dalam ketentuan Pasal 14 UU jaminan Fidusia. Jaminan fidusia lahir dengan adanya perbuatan konstitutif (Pasal 13 UUJF).

Dengan demikian melalui keharusan mendaftarakan jaminan fidusia sebagaimana diatur dalam ketentuan Pasal 11 UU Jaminan Fidusia ini maka UU Jaminan Fidusia telah niemenuhi asas publisitas yang merupakan salah satu dasar hukum jaminan kebendaan.

Mengingat bahwa pemberi fidusia tetap menguasai secara benda yang menjadi obyek jaminan fidusia dan dialah yang memakai serta merupakan pihak yang sepenuhnya memperoleh manfaat ekonomis dari pemakaian benda tersebut, maka pemberi fidusialah yang bertanggungjawab atas semua akibat dan harus memikul semua risiko yang timbul berkaitan dengan pemakaian dan. keadaan benda jaminan tersebut berdasarkan ketentuan Pasal 24 UU jaminan Fidusia. Lebih lanjut, sebagaimana halnya lain maka jaminan fidusia menganut prinsip kebendaan "droit de suite" sebagaimana tampak pada ketentuan Pasal 20 UU jaminan Fidusia. Pengecualian terhadap prinsip ini adalah dalam hal benda yang menjadi obyek fidusia merupakan benda persediaan dan hak kepemilikannya dialihkan dengan cara dan prosedur yang lazim berlaku pada usaha perdagangan dan dengan. memperhatikan persyaratan tertentu sebagaimana dimaksud dalam ketentuan Pasal 21 UU Jaminan Fidusia.

Jaminan fidusia seperti hainya hak agunan atas kebendaan lainya,seperti gadai, hak tanggungan dan hipotek, menganut prinsip "droit de preference" yang berlaku sejak tanggal pendaftarannya di Kantor Pendaftaran Fidusia. Ketentuan Pasal 28 UU jaminan. Fidusia melahirkan suatu adagium yang berbunyi "first registered, first secured". Hal ini berarti bahwa penerima mengambil pelunasan piutangnya atas hasil eksekusi benda yang menjadi obyek jaminan fidusia mendahului kreditur-kreditur lain. Dengan demikian maka sekalipun. pemberi fidusia pailit, hak untuk dari penerima fidusia tidak hapus karena benda yang menjadi jaminan fidusia tidak termasuk dalam harta pailit pemberi jaminan fidusia yang juga berarti memberikan penerima fidusia posisi yang tergolong dalam kreditur separatis.

Dengan memperhatikan sifat dari jaminan fidusia sebagai perjanjian aksesoir dari suatu perjanjian pokok, maka demi hokum jaminan fidusia hapus apabila utang yang bersumber pada perjanjian pokok tersebut dan yang dijamin dengan fidusia hapus.

Berkaitan dengan ketentuan Pasal 25 ayat (3) UU jaminan Fidusia itu maka hal itu diatur guna memberikan kepastian kepada Kantor Pendaftaran Fidusia untuk melakukan pencoretan terhadap pencatatan jaminan fidusia dari Buku Daftar Fidusia dan menerbitkan surat keterangan yang menyatakan bahwa Sertifikat jaminan Fidusia yang bersangkutan tidak berlaku lagi.

Menafsirkan, bahwa yang harus didaftar adalah benda dan ikatan jaminan, akan sangat menguntungkan. Karena dengan terdaftarnya ikatan jaminan dan janji-janji fidusia secara langsung mengikat pihak ketiga.

Dalam suatu perjanjian penjaminan, biasanya antara kreditur dan debitur disepakati janji-janji tertentu, untuk memberikan. suatu posisi yang kuat bagi kreditu dan nantinya sesudah didaftarkan. Dimaksudkan mengikat Pihak ketiga. Oleh karena itu dapat ditafsirkan disini bihwa pendaftaran meliputi, baik pendaftaran. benda maupun ikatan jaminannya, maka semua janji yang termuat dalam akta jaminan fidusia (yang dalam Pasal 13 ayat (2) b dicatat dalam buku daftar Kantor Pendaftaran Fidusia) berlaku dan mengikat pihak ketiga.

\section{Metodologi}

Metode pendekatan yang digunakan dalam penelitian ini menggunakan pendekatan yuridisenipiris. Pendekatan yuridis dipergunakan untuk menganalisa berbagai peraturan dan perundangundangan yang mengatur mengenai perjanjian fidusia dan jaminan fidusia. Sedangkan pendekatan empiris dipergunakan untuk menganalisa hukum bukan semata-mata sebagai suatu 
seperangkat aturan perundang-undangan yang bersifat normatif belaka, akan tetapi hukum dilihat sebagai perilaku masyarakat yang menggejala dan mempola. dalam kehidupan masyarakat, selalu berinteraksi dan berhubungan dengan aspek kemasyarakatan seperti politik, ekonomi, sosial dan budaya. Berbagai temuan lapangan yang bersifat individual akan dijadikan bahan utama dalam mengungkapkan permasalahan yang diteliti dengan berpegang pada. ketentuan yang normatif.

\section{Pembahasan}

\section{Perlindungan Hukum Kreditur}

Sejalan dengan prinsip memberikan kepastian hukum, maka UUJF mengambil prinsip pendaftaran jaminan fidusia. Pendaftaran tersebut diharapkan memberikan kepastian hukum kepada pemberi dan penerima fidusia maupun kepada pihak ketiga.

Dalam suatu perjanjian penjaminan, biasanya memang antara kreditur dan debitur disepakati janji-janji tertentu, yang pada umumnya dimaksudkan untuk memberikan suatu posisi yang kuat bagi kreditur dan nantinya sesudah didaftarkan dimaksudkan untuk juga mengikat pihak ketiga. Oleh karena itu dapat ditafsirkan disini bahwa pendaftaran meliputi, baik pendaftaran benda maupun ikatan jaminannya, maka semua janji yang termuat dalam akta jaminan fidusia (yang dalam Pasal 13 ayat (2) b dicatat dalam buku daftar Kantor Pendaftaran Fidusia) dan mengikat pihak ketiga.

Deskripsi di atas terlihat bahwa para pihak dalam perjanjian jaminan fidusia, baik penerima fidusia maupun pemberi fidusia menurut undang-undang jaminan fidusia sama-sama diberikan perlindungan hukum, bagi pemberi perlindungan berupa adanya hak pakai atas benda jaminan, dan wanprestasi pemberi jaminan fidak akan menyebabkan benda jaminan dengan UUJF adalah diberikannya hak preferent atas piutangnya, dan berlakunya asas droit de suite atas benda jaminan, bagi pihak ketiga asas publisitas dalam perjanjian jaminan fidusia akan memberikan informasi terhadap benda-benda yang difidusiakan.

Jaminan Fidusia harus didaftarkan, seperti yang diatur dalam pasal 11 UUJF. Dengan adanya pendaftaran tersebut, UUJF memenuhi asas publisitas yang merupakan salah satu asas utama hukum jaminan kebendaan. Ketentuan tersebut.dibuat dengan tujuan bahwa benda yang, dijadikan obyek benar-benar merupakan barang kepunyaan debitor atau pemberi fidusia sehingga kalau ada pihak lain yang hendak mengklaim benda tersebut, ia dapat mengetahuinya melalui pengumuman tersebut.

Pendaftaran jaminan fidusia dilakukan pada Kantor Pendaftaran Fidusia dilingkup tugas Departemen Kehakiman dan Hak Asasi Manusia RI, dimana untuk pertama kalinya, kantor tersebut didirikan dengan wilayah kerja mencakup seluruh wilayah negara RI.

Perlindungan hukum dan kepentingan kreditur dalam UUJF dapat dilihat pada Pasal 20 UUJF: "Fidusia tetap mengikuti Benda yang menjadi objek Jaminan fidusia dalam tangan siapapun Benda tersebut berada, kecuali pengalihan atas benda tersebut, kecuali pengalihan atas benda persediaan yang monjadi objek Jaminan Fidusia".

Ketentuan menegaskan bahwa jaminan fidusia mempunyai sifat kebendaan dan berlaku terhadapnya asas droit de suite, kecuali pengalihan atas benda persediaan yang menjadi objek jaminan fidusia.

Perlindungan yang sama juga dapat dilihat dalam Pasal 23 ayat (2) :

Pemberi Fidusia dilarang mengalihkan, menggadaikan, atau menyewakan kepada pihak lain Benda yang menjadi objek jaminan Fidusia yang tidak merupakan benda persediaan, kecuali dengan persetujuan tertulis terlebih dahulu dan Penerima Fidusia".

Sanksi terhadap ketentuan di atas adalah pidana sebagaimana dimaksud dalam Pasal 36 UUJF

"Setiap orang dengan sengaja memalsukan, mengubah, menghilangkan atau dengan cara apapun memberikan keterangan secara menyesatkan, yang jika hal tersebut diketahui oleh salah satu pihak tidak melahirkan perjanjian jaminan fidusia, dipidana dengan pidana penjara paling singkat 1 (satu) tahun dan paling lama 5 (lima) tahun dan denda paling sedikit Rp.10.000.000.- (sepuluh juta rupiah) dan paling banyak Rp.100.000.000.- (seratus juta rupiah)"

Atas segala tindakan dan kelalaian pemberi fidusia, penerima fidusia berdasarkan karena kelalaian tersebut tidak bertanggung jawab, sebagamana dimaksud dalam Pasal 24 UUJF :

"Penerima Fidusia tidak menanggung kewajiban atas akibat tindakan atau kelalaian Pemberi Fidusia baik yang timbul dari hubungan kontraktual atau yang timbul dari perbuatan melanggar hukum sehubungan dengan penggunaan dan pengalihan Benda yang menjadi objek Jaminan Fidusia". 


\section{E. PENUTUP}

1. Kesimpulan

1. Pelaksanaan perlindungan hukum bagi kreditur dalam suatu perjanjian jaminan fidusia lahir pembuatan Ata pembebanan jaminan fidusia yang dibuat secara notariil, dan terus dipertegas dengan pendaftaran dari akta perjanjian tersebut, UUJF telah berupaya memberikan suatu teknis perlindungan bagi kepentingan kreditur, hanya disayangkan system tersebut tidak diaplikasikan dengan menegaskan secara konkrit, dalam suatu sistem pelaksanaan perlindungan melalui eksekusi terhadap jaminan fidusia, yang pada akhimya memberikan pilihan bagi kreditur untuk menempuh jalan damai yang berarti memberikan tambahan biaya lain, dan memberikan apresiasi yang buruk dan tidak maksimal menyangkut perlindungan hukum bagi kreditur.

2. Adapun kelemahan-kelemahan dalam pelaksanaan perlindungan hukum bagi kreditur pada suatu perjanjian perdamaian antara lain disebabkan baik oleh peraturan (UUJF) yang memberikan posisi lemah bagi kreditur seperti tidak adanya ketegasan dalam eksekusi menyangkut pelaksanan eksekusi, padahal objek jaminan fidusia 79 menyangkut benda bergerak yang perpindahannya sangat cepat sehingga rawan terjadi penggelapan selain itu sering dalam suatu perjanjian jamian fidusia tidak adanya penegasan perlu adanya pengawasan oleh penerima fidusia terhadap benda jaminan fidusia yang dikuasai oleh debitur.

\section{Saran}

1. Sebaiknya perlu didiskusikan atau diseminarkan tentang pembentukan lembaga eksekusi terhadap perjanjian jaminan fidusia, mengingat bahwa fidusia merupakan lembaga jaminan atas benda bergerak yang penguasaan fisiknya oleh pemberi fidusia, sehingga secara logika rawan untuk berpindah tangan.

2. Perlu adanya penyadaran hukum dan sosialisasi mengenai pelaksanaan fidusia sehingga kelemahankelemahan yang terdapat dalam UUJF dapat diminimalisasi dalam suatu perjanjian fidusia, misalnya dengan membentuk kesepakatan pengawasan terhadap obyek fidusia.

\section{DAFTAR PUSTAKA}

Badrulzaman. Mariam Darus. 1996. Kitab Undang-Undang Hukum Perdata Buku III, Tentang Hukinit Perikatan Dengan Penjelasannya. Alumni, Bandung. 2001. Kompilasi Hukum Perikatan, Citra Aditya Bakti, Bandung.

Fuady. Munir, 1997, Hukum Bisnis dalam Teori dan Praktek, Citra Aditya Bakti, Bandung.

Hadi. Sutrisno, 2000. Metodologi Research Jilid 1, Penerbit ANDI Yogyakarta,

Kamelo. Tan. H, 2004. Hukum Jaminan Fidusia Suatu Kebutuhan yang Didambakan, Alumni.

Bandung.

Muhammad, Abdul Kadir. 1990. Hukum Perikatan. Citra Aditya Bakti, Bandung.

Prodjodikoro. Wirjono, 2000. Azas Azas Hukum Perjanjian. CV Mandar Maju, Bandung.

Satrio. J, 1999. Hukum Perikatan: Perikatan Pada Umumnya. Alumni, Bandung. 2000. Hitkunt Jaminan Hak Jaminan Kebendaan Fidusia, PT. Citra Aditya Bakti,

Bandung. 2001. Hukum Perikatan, Perikatan yang Lahir dari Undang-Undang Bagian Pertama, Citra Aditya Bakti, Bandung.

Setiawan, R. 1979. Pokok Pokok Hukum Perikatan. Alumni, Bandung.

Situmorang. Victor. M dan Cormetyna Sitanggang. 1990. Grosse Akta.

Sjahdeini. Sutan Remy, 1993, Kebebasan Berkontrak dan Perlindungan Yang Seimbang Bagi Para.

Pihak Dalam Perjanjian di Indonesia, Institut Bankir Indonesia, Jakarta.81

Soekanto. Soerjono, Pengantar Penelitian Hukum, UI Press, Jakarta, 1986.

Soemitro. Ronny Hanitijo, 1985. Metodologi Penelitian Hukum, Ghalia Indonesia, Jakarta. 1990. Metodologi Penelitian Hukum dan Jurimetri, Ghalia Indonesia, Jakarta.

Sofwan, Sri Soedewi Masichoen. 1991, Hukum Perdata : Hukum Benda, Liberty, Jakarta. 
Subekti. R, 2002. Pokok Pokok Hukum Perdata. PT. Intermasa, Jakarta, terutama halaman 122 -126. Subekti dan Tjitrosoedibio. 1970. Kamus Hukum. Pradnya Paramita.Jakarta.

Sumardjono. Maria S.W.,1997 Pedoman Pembuatan Usulan Penelitian (sebuah Panduan Dasar), PT. Gramedia Pustaka Utama, Jakarta.

Sutopo. H.B. 1998. Metodologi Penelitiatt Hukum Kualitatif Bagian II, UNS Press, Surakarta.

Tunggal. Amin Widjaya dan Arif Djohan Tunggal. 1994, Aspek Yuridis dalam Leasing, Rineka Cipta, Bandung.

Widjaya, Gunawan dan Ahmad Yani, 2000, Seri Hukum Bisnis: Jaminan Fidusia. Rajawali Pers, Jakarta.

\section{Makalah:}

Patrik. Purwahid, "Peranan Perjanjian Baku Dalam Masyarakat", makalah pada seminar Masalah Standard Kontrak Dalam Perjanjian Kredit, oleh Ikatan Advokat Indonesia, Surabaya, 11 Desember 1993.

\section{Undang-Undang:}

Kitab Undang-Undang Hukum Perdata.

Undang-Undang Pokok Agraria Nomor 5 Tahun 1960.

Undang-Undang Nomor 42 Tahun 1999 Tentarig Jaminan Fidusia.

Undang-Undang Nomor 30 Tahun 2004 Tentang Jabatan Notaris. 